\title{
PELAKSANAAN DAN MANFAAT KEGIATAN PEMBERDAYAAN MASYARAKAT RAWAN PANGAN DI DKI JAKARTA
}

\author{
Valeriana Darwis
}

Peneliti di Pusat Sosial Ekonomi dan Kebijakan Pertanian

\begin{abstract}
Food insecurity occurs in families experiencing difficulty meeting their food needs. To overcome the Ministry of Maritime Affairs and Fisheries Jakarta has undertaken activities to empower poor communities in Sub Kalibaru Cilincing. Empowerment through the provision of food aid processed. In practice there are some respondents who do not comply with the requirements, including: having no fixed abode, regular income and not all respondents had guidance from NGOs. While the perceived benefits are: (1) partially processed material assistance may be consumed directly, (2) increase the family income, (3) improve the well-being, (4) changes in the mindset of being accustomed to live in groups, save and prepare food reserves.
\end{abstract}

Keywords: Empowerment and Food Insecurity

\section{PENDAHULUAN}

Rawan pangan (food insecurity) merupakan kondisi dimana keluarga mengalami kesulitan didalam memenuhi kebutuhan pangan. Menurut Sri Sumarmi rawan pangan dapat dikelompokkan kedalam keadaan kronis (chronical food insecurity) dan sementara (transitory food insecurity). Rawan pangan kronis merupakan kondisi kurang pangan (untuk tingkat rumah tangga berarti kepemilikan pangan lebih sedikit dari pada kebutuhan dan untuk tingkat individu konsumsi pangan lebih rendah dari kebutuhan biologis) yang terjadi sepanjang waktu. Sedangkan pengertian rawan pangan sementara mencakup rawan pangan musiman (seasonal). Rawan pangan ini dapat terjadi karena adanya kejutan (shock) yang mendadak dan tak terduga seperti kekeringan dan ledakan serangan hama yang sangat membatasi kepemilikan pangan oleh rumah tangga, terutama mereka yang berada di pedesaan. Bagi rumah tangga di perkotaan rawan pangan tersebut dapat disebabkan antara lain oleh pemutusan hubungan kerja

Daerah perkotaan tidak lepas dari ancaman kerawanan pangan. Menurut Tjuk Eko Hari Basuki salah satu faktor utama penyebab kerawanan pangan di daerah perkotaan adalah kemiskinan (Sinar Tani). Provinsi DKI Jakarta merupakan salah satu kota yang tinggi tingkat kerawanan pangannya.
Setiap tahun Provinsi DKI selalu kedatangan masyarakat rural yang ingin merubah nasib. Hal ini disebabkan karena sampai sekarang status DKI selain ibukota negara juga sebagai kota pusat perdagangan, parawisata, bisnis dan jasa. Tetapi yang menjadi permasalahan pendatang rural tersebut umumnya tidak dibekali oleh ilmu pengetahuan atau ketrampilan yang memadai. Kondisi ini menyebabkan jumlah penduduk miskin tidak pernah berkurang bahkan cenderung mengalami penambahan setiap tahunnya. Menurut Bappenas (2002) kemiskinan adalah suatu situasi atau kondisi yang dialami seseorang atau kelompok orang yang tidak mampu menyelenggarakan hidupnya sampai suatu taraf yang dianggap manusiawi.

Salah satu upaya dalam mengentaskan kemiskinan adalah program pemberdayaan. Pemberdayaan adalah pilihan, kebebasan, partisipasi dalam pengambilan keputusan, martabat, penghargaan, kerjasama dan rasa saling memiliki pada komunitas (Gonsalves et al, 2005). Prinsip pemberdayaan adalah menempatkan masyarakat sebagai aktor utama dalam seluruh rangkaian pembangunan. Pemberdayaan menempatkan masyarakat sebagai subyek untuk mengenali permasalahan, ikut dalam perencanaan program akan menghasilkan kemandirian yang tinggi (Mubyarto,1984 ; Sajogyo, 1982). Menurut Syahyuti (2007) pemberdayaan berarti 
mempersiapkan masyarakat untuk memperkuat diri dan kelompok mereka dalam berbagai hal, mulai dari sosial kelembagaan, kepemimpinan, sosial ekonomi dan politik dengan menggunakan basis kebudayaan mereka sendiri. Pemberdayaan dapat dipandang sebagai proses bertingkat yang melibatkan individu, komunitas dan organisasi. Keterlibatan individu berkaitan dengan keterlibatan dalam pengambil keputusan, sedangkan komunitas berhubungan dengan dampak keterlibatan. Sementara itu organisasi adalah struktur yang mengakomodasi (mediator) dan sekaligus memfasilitasi kegiatan aksi bersama berbasis komunitas (Checkoway, 1995).

Mengatasi masalah kerawanan pangan di Provinsi DKI pemerintah melalui Dinas Kelautan dan Perikanan telah membuat suatu program pemberdayaan masyarakat yang bertujuan untuk meningkatkan akses pangan masyarakat dan meningkatkan kemampuan masyarakat miskin dalam menggerakkan roda perekonomian mereka. Program pemberdayaan yang diinisiasi oleh Bidang Ketahanan Pangan sudah dilaksanakan sejak tahun 2009 di 4 Kelompok KK Rawan Pangan dan 2 Kelompok Gizi Buruk yang berada di RW 08 Kelurahan Kali Baru, Kecamatan Cilincing, Jakarta Utara (2009) dan 8 kelompok KK rawan pangan dan 4 kelompok KK Gizi Buruk di RW 03. 04 dan 06 (2010). Setiap tahun kegiatan ini terus berkembang dan sampai sekarang jumlah KK yang telah mengikuti program tersebut sebanyak $580 \mathrm{KK}$ yang tersebar di semua RW Kelurahan Kalibaru.

Uraian diatas bertujuan untuk mengetahui bagaimana pelaksanaan kegiatan pemberdayaan yang sudah dilaksanakan oleh Dinas Kelautan dan Perikanan, serta manfaat apa yang dirasakan oleh masyarakat yang menerima program tersebut.

\section{METODE PENELITIAN}

Penelitian ini dilaksanakan tahun 2012 dengan mengambil lokasi pelaksanaan program pemberdayaan masyarakat rawan pangan di 8 RW pada Kelurahan Kalibaru Kecamatan Cilincing. Agar terlihat variasi pelaksanaan serta ragam permasalahannya, maka responden dibedakan berdasarkan jenis pemanfaatan bantuan pangan yang diberikan. Responden dipilih secara acak sesuai dengan kondisi pada saat dilakukan survay dan masing-masing jenis usaha respondennya berkisar dari 15 sampai 30 orang (Tabel 1).

Data yang dipergunakan terdiri atas data primer dan data sekunder. Data primer diperoleh melalui wawancara langsung dengan responden dengan mempergunakan pertanyaan terstruktur (kuesioner). Adapun kuesioner yang dipergunakan berisikan pertanyaan tentang : (i) karakteristik rumah tangga; (ii) bantuan pangan yang diterima dan pelaksanaan kegiatan di peserta program; (iii) manfaat dalam melaksanakan program, (iv) indikator kemiskinan berdasarkan 14 indikator kemiskinan yang dikeluarkan oleh BPS, (v) ketahanan pangan dari aspek ketersediaan dan aspek konsumsi; dan (vi) pola pikir. Sementara data sekunder yang dipergunakan antara lain monograf atau profil masing-masing RW yang mendapatkan program, monograft atau profil

Tabel 1. Lokasi Pelaksanaan Survay Penelitian

\begin{tabular}{lrrrrrrrrr}
\hline RW & \multicolumn{7}{c}{ Pemanfaatan } & \multicolumn{2}{c}{ Jumlah } \\
\cline { 2 - 9 } & Nasi & Gorengan & Peyek & Kac.Ijo & Pempek & Bakso & Es Buah & Candil & Orang \\
IV & 2 & 1 & 4 & 3 & 0 & 3 & 0 & 0 & 13 \\
V & 3 & 4 & 2 & 1 & 4 & 3 & 1 & 2 & 20 \\
VI & 6 & 6 & 6 & 5 & 8 & 15 & 10 & 6 & 62 \\
VII & 0 & 0 & 1 & 1 & 0 & 0 & 1 & 1 & 4 \\
VIII & 5 & 1 & 6 & 7 & 1 & 4 & 3 & 7 & 34 \\
IX & 0 & 1 & 0 & 0 & 0 & 1 & 1 & 1 & 4 \\
X & 1 & 1 & 1 & 0 & 1 & 0 & 0 & 0 & 4 \\
XII & 7 & 7 & 1 & 1 & 3 & 1 & 2 & 5 & 27 \\
TTL & 24 & 21 & 21 & 18 & 17 & 27 & 18 & 22 & 168 \\
\hline
\end{tabular}


Kelurahan Kalibaru, monograft atau profil Kecamatan Cilincing dan DKI dalam angka.

Cara mengetahui posisi kemiskinan di

Kelurahan Kalibaru dipergunakan teknik eksplorasi data sekunder yang kemudian dianalisis dengan mempergunakan tabulasi silang (cross tabulation). Untuk mengetahui pelaksanaan kegiatan dan dampak sosial ekonomi program pemberdayaan masyarakat rawan pangan dipergunakan teknik pengumpulan data melalui wawancara yang kemudian data tersebut dianalisis secara deskriptif kuantitatif yang nantinya ditampilkan dalam bentuk tabel - tabel.

\section{HASIL DAN PEMBAHASAN}

Menurut BPS pada tahun 2007 jumlah KK miskin yang ada di DKI sebanyak 150.913 orang dan paling banyak berdomisili di wilayah Jakarta Utara, yaitu sebanyak 48.469 orang atau $32,1 \%$ dari total KK miskin. Penduduk miskin yang ada di Jakarta Utara tersebar di 6 kecamatan dan yang paling banyak penduduk miskinnya di Kecamatan Cilincing, yaitu 16.312 orang atau 33,65 persen dari total KK miskin. Di Kecamatan Cilincing KK miskin menyebar di 7 Kelurahan yang ada. Kelurahan yang paling banyak KK miskinnya berada di Kelurahan Kalibaru, dengan kontribusi KK miskin secara total sebanyak 6.243 orang atau 38,27 persen dari total $\mathrm{KK}$ miskin di wilayah Jakarta Utara.

Program pemberdayaan ini pada dasarnya ingin merubah perilaku masyarakat dalam meningkatkan akses pangan mereka dengan melakukan pembinaan, pemberdayaan, penyuluhan baik administrasi, keuangan, teknis, dan pemasaran kepada kelompok masyarakat. Bantuan pangan yang diberikan disesuaikan dengan keinginan dan keahlian dari kelompok masyarakat itu sendiri dengan terlebih dahulu melakukan karakterisasi sasaran. Bantuan pangan dilakukan bertahap sesuai dengan kebutuhan dari masyarakat sasaran. Sebelum mendapatkan bantuan pangan, masyarakat sasaran diberikan pembinaan, penyuluhan dan pemberdayaan tentang segala sesuatu yang berkaitan dengan masalah teknis, administrasi, keuangan dan lainnya sesuai dengan tingkat pendidikan dan pengalaman masyarakat tersebut.
Pemberian pangan ini sebagian dapat digunakan untuk dikonsumsi oleh anggota keluarga dan sebagian lagi diolah menjadi bahan pangan yang dapat dikembangkan menjadi unit usaha yang mapan, sehingga dapat menjamin pendapatan secara kontinyiu. Pembinaan dan pemberdayaan masyarakat dilakukan oleh Lembaga Swadaya Masyarakat (LSM) yang peduli terhadap masyarakat miskin selama 6 (enam) bulan dan dilanjutkan dengan para penyuluh dan pendamping untuk pembinaan lebih lanjut. Peserta yang akan mendapatkan program adalah penduduk yang memiliki kriteria seperti: (1) sudah berkeluarga, (2) memiliki KK dan KTP Provinsi DKI Jakarta, (3) bertempat tinggal di Kelurahan Kali Baru Jakarta Utara, (4) mempunyai tempat tinggal yang tetap, (5) tidak mempunyai penghasilan yang tetap dan (6) bersedia melakukan usaha pangan. Bagi keluarga yang telah memenuhi persyaratan akan mendapatkan bantuan pangan.

\section{Pelaksanaan Program Pemberdayaan}

Umur responden yang menerima program pemberdayaan berkisar dari 41.8 tahun sampai 53.75 tahun (Tabel 2). Kalau dilihat dari umur responden terlihat bahwa responden masih dalam usia produktif. Dari segi pendidikan umumnya responden sudah menamatkan Sekolah Dasar, artinya responden tidak buta huruf dan sudah mengetahui dasar perhitungan matematika. Dalam dunia bisnis atau usaha, tidak buta huruf dan bisa menghitung merupakan basis utama dalam menjalankan usahanya. Dari segi tanggungan jumlah anggota keluarga paling banyak empat orang dan paling sedikit 2 atau 3 orang. Dari jumlah tanggungan tersebut yang tidak sekolah sama sekali paling banyak di responden yang mengusahakan pempek (2 orang) dan yang paling sedikit di responden yang mengusahakan jenis goreng-gorengan. Responden yang menerima bantuan pangan jenis pekerjaannya sangat bervariasi untuk setiap jenis usaha dan umumnya yang paling banyak adalah buruh dan dagang/usaha mikro.

Bantuan pangan yang diberikan merupakan satu paket usaha pangan seperti (1) usaha nasi bantuan yang diberikan dalam bentuk: beras, telur, minyak goreng, mie, kecap; (2) Goreng-gorengan: singkong, pisang, 
Tabel 2. Karakteristik Kepala Keluarga Penerima Program

\begin{tabular}{|c|c|c|c|c|c|c|c|c|c|}
\hline No & Uraian & Nasi & $\begin{array}{l}\text { Gore- } \\
\text { ngan }\end{array}$ & Peyek & $\begin{array}{l}\text { Kac. } \\
\text { IJo }\end{array}$ & Pempek & Bakso & $\begin{array}{c}\text { Es } \\
\text { Buah }\end{array}$ & Candil \\
\hline 1. & Umur KK (Thn) & 53.75 & 42.29 & 48.33 & 51.56 & 44.6 & 45.3 & 41.8 & 46.2 \\
\hline 2. & Pendidikan KK (Thn) & 5.71 & 6.63 & 6 & 6.61 & 7.2 & 7.1 & 7.1 & 7.4 \\
\hline 3. & $\begin{array}{l}\text { Pekerjaan Utama KK } \\
\text { (org) } \\
\text { 1. Buruh }\end{array}$ & 5 & 3 & 9 & 5 & 3 & 9 & 7 & 9 \\
\hline & 2. Sopir & 2 & 1 & 2 & 1 & 2 & 0 & 0 & 0 \\
\hline & 3. Nelayan & 4 & 1 & 2 & 2 & 4 & 5 & 1 & 1 \\
\hline & 4. Dagang & 5 & 6 & 5 & 4 & 7 & 10 & 8 & 7 \\
\hline & 5. Karyawan Swasta & 1 & 6 & 1 & 1 & 0 & 2 & 2 & 3 \\
\hline & 6. Pengangguran & 7 & 1 & 1 & 3 & 1 & 1 & 0 & 2 \\
\hline & 7. Hansip & 0 & 1 & 1 & 0 & 0 & 0 & 0 & 0 \\
\hline & 8. Ojek & 0 & 2 & 0 & 2 & 0 & 0 & 0 & 0 \\
\hline 4. & Jumlah Tanggungan (org) & 3 & 3.04 & 3.86 & 2.28 & 3.1 & 2.8 & 2.6 & 3.4 \\
\hline 5. & Anak masih sekolah (org) & 1.04 & 1.58 & 1.38 & 0.89 & 1.6 & 1.8 & 1.5 & 1.9 \\
\hline 6. & $\begin{array}{l}\text { Anak belum sekolah } \\
\text { (org) }\end{array}$ & 0.38 & 0.17 & 0.76 & 0.28 & 1.5 & 1.1 & 1.0 & 1.0 \\
\hline 7. & Anak tidak sekolah (org) & 0.71 & 0.63 & 0.90 & 0.22 & 2.2 & 1.2 & 1.0 & 1.5 \\
\hline
\end{tabular}

minyak goreng, tepung terigu; (3) Peyek: kacang tanah, tepung terigu, minyak goreng, singkong, teri; (4) Kacang ijo: kacang ijo, ketan hitam, gula merah, gula pasir; (5) Pempek: sagu, tepung terigu, minyak goreng, gula merah; (6) Bakso: daging, sagu, mie, kecap; (7) Es buah: nanas, pepaya, melon, jambu, belimbing, gula putih dan (8) Candil: gula pasir, gula merah, tepung beras, ubi. Informasi tentang adanya kegiatan bantuan pangan umumnya diperoleh responden dari konsultan yang menjadi pendamping kegiatan (Tabel 3). Selain konsultan informasi tentang kegiatan sekaligus mengajak masyarakat untuk ikut kegiatan tersebut dilaksanakan oleh pengurus RW. Ada juga responden yang mendapatkan informasi dari teman dan inisiatif sendiri. Untuk mengikuti kegiatan ini diperlukan beberapa persyaratan dan umumnya responden bisa memenuhi persyaratan tersebut. Hanya beberapa orang saja yang tidak dapat memenuhi persyaratan tetapi bisa mendapatkan bantuan pangan ini. Persyaratan yang tidak terpenuhi ini antara lain : tempat tinggal tetap, penghasilan tidak menentu dan siap mengikuti kegiatan sampai selesai. Bagi yang berminat mendapatkan bantuan pangan diharuskan untuk mengikuti kegiatan sosialisasi dan pemberdayaan kegiatan. Sosialisasi dilaksanakan pada intinya untuk menyampaikan aturan main dan tujuan kegiatan. Sementara itu permberdayaan kegiatannya berupa pelatihan cara pengolahan bahan pangan bantuan menjadi barang atau produk yang siap untuk dijual. Selain itu ada juga kegiatan pelatihan tentang manajemen keuangan dan standar produksi, pada kegiatan ini ternyata tidak semua responden yang mengikutinya atau ada responden yang hanya mengikuti pelatihan manajemen keuangan saja.

Kegiatan sosialisasi dan pelatihan cara mengolah bahan pangan, responden merasakan bahan pangan yang diberikan sudah sesuai dengan kebutuhan dan keahlian responden. Bahan pangan yang diberikan tidak semua dipergunakan untuk bahan baku olahan, bagi $18 \%$ responden yang mengusahakan bakso bahan pangan bantuan tersebut dipergunakan untuk konsumsi. Bantuan bahan pangan yang dikonsumsi langsung diatas $10 \%$ terjadi juga di responden yang mengusahakan candil dan es buah, masing-masing yaitu : $16.8 \%$ dan $11.2 \%$. Responden yang paling sedikit mengkonsumsi bantuan bahan pangan adalah responden yang mengusahakan peyek.

Selama melaksanakan kegiatan pemberdayaan responden dibina oleh Lambaga Swadaya Masyarakat. Dalam melaksanakan pembinaan ternyata tidak seluruh responden yang mendapatkan binaan dan jumlah responden yang dibina juga tidak sama antar jenis usaha. Pembinaan yang paling banyak dilakukan oleh LSM adalah kegiatan usaha kacang ijo, sebaliknya usaha yang paling 
Valeriana Darwis : Pelaksanaan Dan Manfaat Kegiatan Pemberdayaan Masyarakat...

sedikit dibina adalah usaha pempek. Pembinaan yang dilakukan oleh instansi pemerintah tidak pernah diikuti oleh seluruh responden

\section{Manfaat Program Pemberdayaan}

Bantuan pangan yang diperoleh oleh sebagian responden dipergunakan sebagai tambahan bahan baku olahan usaha yang sudah dilaksanakan dan sebagian lagi dipergunakan sebagai usaha baru yang diharapkan bisa menjadi sumber tambahan pendapatan keluarga. Responden yang paling banyak mempergunakan bantuan pangan ini sebagai usaha baru adalah usaha kacang ijo, yaitu sebanyak $83.3 \%$ dan yang paling sedikit adalah usaha nasi yaitu $16.7 \%$ (Tabel 4). Kalau dilihat dari pendapatan rata-rata perhari untuk responden yang baru mengusahakannya, yang paling banyak adalah usaha kacang ijo dan yang paling sedikit adalah usaha bakso yaitu masing-masing Rp57.000 dan Rp34.000. Sementara itu rata-rata pendapatan untuk usaha lanjutan yang paling besar terdapat diusaha gorengan yang hampir mencapai Rp100.000 perhari, sebaliknya usaha candil merupakan usaha lanjutan yang paling sedikit yaitu Rp40.000 perhari.

Tabel 3. Pelaksanaan Bantuan Pangan (\% Responden)

\begin{tabular}{|c|c|c|c|c|c|c|c|c|c|}
\hline No & Uraian & Nasi & $\begin{array}{l}\text { Gore- } \\
\text { ngan }\end{array}$ & Peyek & $\begin{array}{l}\text { Kc } \\
\text { Ijo }\end{array}$ & Pempek & Bakso & $\begin{array}{l}\text { Es } \\
\text { Buah }\end{array}$ & Candil \\
\hline \multirow[t]{5}{*}{1.} & Informasi Kegiatan & & & & & & & & \\
\hline & Konsultan & 75.0 & 80.9 & 76.2 & 61.1 & 82.3 & 81.5 & 88.9 & 68.2 \\
\hline & Pengurus RW & 12.5 & 14.3 & 23.8 & 22.2 & 11.7 & 7.4 & 5.6 & 18.1 \\
\hline & Inisiatif sendiri & 8.3 & 4.8 & 0 & 16.7 & 0 & 0 & 0 & 0 \\
\hline & Teman & 4.2 & 0 & 0 & 0 & 6.0 & 11.1 & 5.6 & 13.7 \\
\hline \multirow[t]{11}{*}{2.} & Syarat Kegiatan & & & & & & & & \\
\hline & $\overline{\mathrm{Ada}}$ & 100 & 100 & 100 & 100 & 100 & 100 & 100 & 100 \\
\hline & Tidak & 0 & 0 & 0 & 0 & 0 & 0 & 0 & 0 \\
\hline & Jika ada syaratnya: & & & & & & & & \\
\hline & KTP & 100 & 100 & 100 & 100 & 100 & 100 & 100 & 100 \\
\hline & Foto $3 \times 4$ & 100 & 100 & 100 & 100 & 100 & 100 & 100 & 100 \\
\hline & Tempat Tinggal Tetap & 100 & 100 & 100 & 100 & 83.3 & 100 & 100 & 100 \\
\hline & Penghasilan tidak & 100 & 100 & 100 & 100 & 88.9 & 100 & 100 & 100 \\
\hline & menentu & 100 & 100 & 100 & 100 & 88.9 & 96.3 & 100 & 100 \\
\hline & Siap Menjalankan & & & & & & & & \\
\hline & $\begin{array}{l}\text { kegiatan sampai selesai } \\
\text { Soialisasi Keoiatan }\end{array}$ & & & & & & & & \\
\hline \multirow{2}{*}{3.} & $\frac{\text { Sosialisasi Kegiatan }}{\text { Ada }}$ & 100 & 100 & 100 & 100 & 100 & 100 & 100 & 100 \\
\hline & Tidak & 0 & 0 & 0 & 0 & 0 & 0 & 0 & 0 \\
\hline \multirow[t]{6}{*}{4.} & Pelatihan Kegiatan & & & & & & & & \\
\hline & $\overline{\text { Ada }}$ & 100 & 100 & 100 & 100 & 100 & 100 & 100 & 100 \\
\hline & Tidak & 0 & 0 & 0 & 0 & 0 & 0 & 0 & 0 \\
\hline & Jika ada dalam bentuk. & & & & & & & & \\
\hline & Manajemen keuangan & 45.8 & 33.3 & 47.6 & 22.2 & 29.4 & 25.9 & 44.4 & 36.7 \\
\hline & $\begin{array}{l}\text { Manajemen Keuangan, } \\
\text { standar produksi }\end{array}$ & 54.2 & 66.7 & 52.3 & 77.8 & 70.6 & 74.1 & 55.6 & 63.3 \\
\hline \multirow[t]{3}{*}{5.} & Pemberdayaan Kegiatan & & & & & & & & \\
\hline & Ada & 100 & 100 & 100 & 100 & 100 & 100 & 100 & 100 \\
\hline & Tidak & 0 & 0 & 0 & 0 & 0 & 0 & 0 & 0 \\
\hline \multirow[t]{4}{*}{6.} & Apakah bantuan sesuai & & & & & & & & \\
\hline & dengan kebutuhan & 100 & 100 & 100 & 100 & 100 & 100 & 100 & 100 \\
\hline & $\overline{\text { Iya }}$ & 0 & 0 & 0 & 0 & 0 & 0 & 0 & 0 \\
\hline & Tidak & & & & & & & & \\
\hline \multirow[t]{3}{*}{7.} & Apakah bantuan sesuai & & & & & & & & \\
\hline & dengan keahlian & 100 & 100 & 100 & 100 & 100 & 100 & 100 & 100 \\
\hline & Iya & 0 & 0 & 0 & 0 & 0 & 0 & 0 & 0 \\
\hline
\end{tabular}


Valeriana Darwis : Pelaksanaan Dan Manfaat Kegiatan Pemberdayaan Masyarakat...

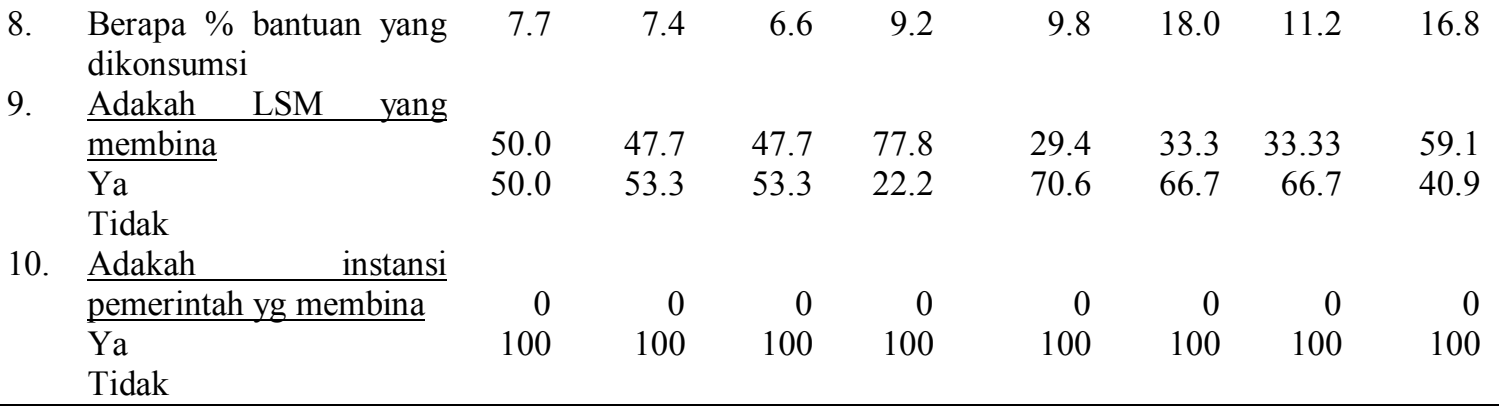

Hampir seluruh responden yang mendapatkan bantuan pangan melakukan kegiatan menabung dari keuntungan usahanya. Menabung merupakan aktivitas yang harus dilakukan, karena dengan menabung bisa menjamin ketersediaan modal untuk berusaha di kemudian hari. Tetapi alasan utama dalam menabung bagi responden adalah untuk kebutuhan keluarga di masa yang akan datang, terutama untuk biaya pendidikan dan kesehatan. Bagi keluarga yang mempunyai tanggungan lebih banyak dan tidak mempunyai sumber pendapatan lainnya menjadi alasan utama kenapa tidak bisa melakukan kegiatan menabung.

Tempat menabung seluruh responden dilakukan di ketua kelompok. Ada beberapa alasan yang menyebabkan responden tidak mau menabung di bank. Alasan tersebut bisa dikelompokan kedalam : (i) lokasi rumah ketua kelompok tidak jauh dari rumah responden, kondisi ini menyebabkan responden tidak mengeluarkan biaya transportasi ;

Tabel 4. Manfaat Dalam Melaksanakan Program (\% Responden)

\begin{tabular}{|c|c|c|c|c|c|c|c|c|c|}
\hline No & Uraian & Nasi & $\begin{array}{l}\text { Gore- } \\
\text { ngan }\end{array}$ & Peyek & $\begin{array}{l}\text { Kc } \\
\text { Ijo }\end{array}$ & Pempek & Bakso & $\begin{array}{c}\text { Es } \\
\text { Buah }\end{array}$ & Candil \\
\hline \multirow[t]{5}{*}{1.} & Jenis Usaha & & & & & & & & \\
\hline & $\overline{\text { Baru }}$ & 16.7 & 42.9 & 47.6 & 83.3 & 29.4 & 40.7 & 55.6 & 68.2 \\
\hline & $\begin{array}{ll}\text { Rata-rata } & \text { pendapatan } \\
\text { perhari }(000) & \end{array}$ & 48 & 51 & 50 & 57 & 53 & 34 & 51 & 38 \\
\hline & Lanjutan & 83.4 & 57.1 & 52.4 & 16.7 & 70.6 & 59.3 & 44.4 & 31.8 \\
\hline & $\begin{array}{ll}\text { Rata-rata } & \text { pendapatan } \\
\text { perhari }(000) & \end{array}$ & 75 & 97 & 43 & 48 & 60 & 77 & 47 & 40 \\
\hline \multirow[t]{6}{*}{2.} & Apakah keuntungannya & & & & & & & & \\
\hline & Ja & 100 & 90.5 & 100 & 100 & 94.1 & 100 & 100 & 100 \\
\hline & Cadangan Modal & 25.0 & 23.8 & 19.1 & 0 & 11.8 & 33.3 & 38.9 & 36.4 \\
\hline & $\begin{array}{l}\text { Cadangan modal dan } \\
\text { keperluan keluarga }\end{array}$ & 75.0 & 66.2 & 80.9 & 100 & 88.2 & 66.7 & 61.1 & 63.6 \\
\hline & $\begin{array}{l}\text { Tidak } \\
\text { Jika tidak kenapa }\end{array}$ & 0 & 9.5 & 0 & 0 & 5.9 & 0 & 0 & 0 \\
\hline & $\begin{array}{l}\text { Habis untuk kebutuhan } \\
\text { sehari-hari }\end{array}$ & - & 9.5 & - & - & 5.9 & - & - & - \\
\hline \multirow[t]{7}{*}{3.} & Dimana ditabung & & & & & & & & \\
\hline & $\begin{array}{l}\text { Rumah ketua } \\
\text { Jika dirumah ketua } \\
\text { alasannya }\end{array}$ & 100 & 100 & 100 & 100 & 100 & 100 & 100 & 100 \\
\hline & Dekat & 100 & 100 & 100 & 100 & 100 & 100 & 100 & 100 \\
\hline & $\begin{array}{l}\text { Tidak ada biaya } \\
\text { administrasi }\end{array}$ & 100 & 100 & 100 & 100 & 100 & 100 & 100 & 100 \\
\hline & Tidak berbelit & 100 & 100 & 100 & 100 & 100 & 100 & 100 & 100 \\
\hline & Bank & 0 & 0 & 0 & 0 & 0 & 0 & 0 & 0 \\
\hline & Jika di bank kenapa & - & - & - & - & - & - & - & \\
\hline
\end{tabular}


(ii) tidak ada biaya administrasi, responden tidak perlu mengisi formulir untuk membuka tabungan, membeli materai atau biaya administrasi lainnya ; (iii) tidak berbelit-belit, dalam arti kata apabila ingin mengambil uang diketua responden dapat melakukan kapan saja (tidak terikat waktu jam kerja). Ada 14 indikator kemiskinan yang telah ditetapkan oleh BPS yang melekat di keluarga miskin. Dari beberapa indikator tersebut, terlihat adanya perubahan positif di keluarga responden setelah mendapatkan bantuan bahan pangan. Hal ini bisa terlihat dari 1 dan 2 responden usaha bakso mengalami perubahan peningkatan luas lantai tanah dan jenis lantai yang dulunya dari tanah sekarang sudah disemen (plester) (Tabel 5). Masing-masing satu responden kecuali responden usaha kacang ijo dan pempek mengalami perubahan jenis dinding yang berkualitas rendah menjadi dinding berkualitas sedang. Untuk kepemilikan fasilitas buang air besar responden usaha candil mengalami kemajuan yang sangat signifikan, yaitu 14 responden sekarang sudah mempunyai fasilitas buang air besar sendiri.

Fasilitas listrik dan sumber air minum sekarang sudah dimiliki oleh responden, sebelumnya 1 responden usaha candil dan 2 responden usaha pempek belum memiliki fasilitas tersebut. Yang mengalami perubahan sangat signifikan hampir di semua jenis usaha adalah perubahan pemakaian kayu bakar/minyak tanah sebagai bahan untuk memasak berganti dengan mempergunakan gas.

Frekuensi makan dalam sehari mengalami peningkatan dari yang dua kali menjadi tiga kali dalam sehari, perubahan ini terjadi disemua jenis usaha yang dilakukan oleh responden. Selain itu perubahan positif terlihat juga dari konsumsi daging/susu/ayam yang dulunya satu sekali sekarang sudah bisa lebih dari satu kali seminggu.

Tabel 5. Perubahan Indikator Kemiskinan Setelah Mengikuti Kegiatan (responden)

\begin{tabular}{|c|c|c|c|c|c|c|c|c|c|}
\hline No & Uraian & Nasi & Gorengan & Peyek & Ke Ijo & Pempek & Bakso & Es Buah & Candil \\
\hline 1. & Luas lantai rumah $<8 \mathrm{~m}$ & 0 & 0 & 0 & 0 & 0 & 1 & 0 & 0 \\
\hline 2. & $\begin{array}{l}\text { Jenis lantai terbuat dari } \\
\text { tanah/bambu/kayu murahan }\end{array}$ & 1 & 0 & 0 & 0 & 0 & 2 & 0 & 0 \\
\hline 3. & $\begin{array}{l}\text { Jenis dinding tempat tinggal terbuat } \\
\text { dari bambu/rumbia/kayu berkualitas } \\
\text { rendah/tembok tanpa plester }\end{array}$ & 1 & 1 & 1 & 0 & 0 & 1 & 1 & 1 \\
\hline 4. & Memiliki fasilitas buang air besar & 1 & 0 & 0 & 1 & 0 & 1 & 14 & 4 \\
\hline 5. & $\begin{array}{l}\text { Sumber penerangan menggunakan } \\
\text { listrik }\end{array}$ & 0 & 0 & 0 & 0 & 0 & 0 & 0 & 1 \\
\hline 6. & $\begin{array}{l}\text { Sumber air minum berasal dari } \\
\text { sumur/mata air tidak terlindungi/ } \\
\text { sungai/air hujan }\end{array}$ & 0 & 0 & 0 & 0 & 2 & 0 & 0 & 1 \\
\hline 7. & $\begin{array}{l}\text { Apaka Bapak/Ibu menggunakan kayu } \\
\text { bakar/arang/minyak tanah untuk } \\
\text { memasak sehari-hari }\end{array}$ & 9 & 8 & 9 & 5 & 7 & 4 & 0 & 9 \\
\hline 8. & $\begin{array}{l}\text { Apakah keluarga Bapak/Ibu } \\
\text { mengkonsumsi daging/susu/ayam satu } \\
\text { kali seminggu }\end{array}$ & 0 & 1 & 1 & 1 & 1 & 4 & 1 & 1 \\
\hline 9. & $\begin{array}{l}\text { Apakah keluarga Bapak/Ibu membeli } \\
\text { hanya satu stel pakaian baru setahun } \\
\text { sekali }\end{array}$ & 1 & 0 & 0 & 1 & 1 & 3 & 0 & 0 \\
\hline 10. & $\begin{array}{l}\text { Berapa kali keluarga Bapak/ibu makan } \\
\text { dalam sehari }\end{array}$ & & & & & & & & \\
\hline & $1 \mathrm{kali}$ & 0 & 0 & 0 & 0 & 0 & 0 & 0 & 0 \\
\hline & 2 kali & 3 & 7 & 5 & 3 & 4 & 4 & 4 & 2 \\
\hline & 3 kali & 3 & 7 & 5 & 3 & 4 & 4 & 4 & 2 \\
\hline 11. & $\begin{array}{l}\text { Jika ada keluarga yang sakit, apakah } \\
\text { berobat ke puskesmas } \\
\text { /poliklinik/dokter }\end{array}$ & 0 & 0 & 0 & 0 & 0 & 0 & 0 & 0 \\
\hline 12. & $\begin{array}{l}\text { Apakah pendapatan Bapak/Ibu kurang } \\
\text { dari Rp600.000 per bulan }\end{array}$ & 1 & 5 & 5 & 1 & 1 & 3 & 2 & 0 \\
\hline 13. & $\begin{array}{l}\text { Apakah pendidikan tertinggi } \\
\text { Bapak/Ibu sebagai KK: Tidak Pernah } \\
\text { sekolah/tidak tamat SD/hanya SD }\end{array}$ & 0 & 0 & 0 & 0 & 0 & 0 & 0 & 0 \\
\hline 14. & $\begin{array}{l}\text { Apakah Bapak/Ibu memiliki } \\
\text { tabungan/barang yang mudah dijual } \\
\text { dengan nilai Rp500.000 }\end{array}$ & 1 & 2 & 2 & 1 & 0 & 1 & 1 & 1 \\
\hline
\end{tabular}


Manfaat lain yang dirasakan oleh responden setelah mengikuti program pemberdayaan ini adalah : responden sudah mulai menyediakan cadangan pangan untuk kebutuhan beberapa hari kedepan, meningkatkan konsumsi beragam, berimbang, bergizi dan aman (B3A), sementara perubahan pola pikir direpresentasikan dari hidup berkelompok dan menabung sebagian dari pendapatan.

\section{SIMPULAN}

Berdasarkan data BPS maka sangat wajar lokasi yang dipilih untuk melakukan kegiatan pemberdayaan masyarakat miskin dilaksanakan di Kelurahan Kalibaru Kecamatan Cilincing, karena lokasi ini merupakan penduduk yang paling banyak miskinnya di Jakarta Utara dan Wilayah Jakarta Utara merupakan wilayah yang paling miskin di Provinsi DKI. Sebelum melaksanakan kegiatan, Dinas Kelautan dan Perikanan DKI terlebih dahulu melakukan sosialisasi, pelatihan baik secara administrasi maupun pengolahan produk yang siap jual. Dengan adanya kegiatan ini maka seluruh responden merasakan sudah mendapatkan bantuan pangan sesuai dengan kebutuhan dan keahlian yang dimiliki. Informasi adanya bantuan pangan tidak hanya diperoleh dari konsultas saja, tetapi ada juga responden yang mendapatkan dari pengurus RW, teman, dan inisiatif sendiri. Untuk ikut serta dalam kegiatan tersebut harus memenuhi persyaratan administrasi, tetapi dalam prakteknya masih ada beberapa responden yang tidak memenuhi administrasi tersebut, khususnya pada bagian penghasilan tidak menentu, mempunyai tempat tinggal tetap dan mau menjalankan kegiatan sampai selesai. Selain itu responden tidak seluruhnya mendapatkan binaan dari LSM, bahkan tidak ada satupun institusi pemerintah daerah selain Dinas Kelautan dan Perikanan yang melakukan pendampingan atau pembinaan lanjutan.

Manfaat yang dirasakan oleh responden dengan adanya kegiatan ini antara lain: (1) meskipun tidak banyak bahan bantuan pangan tersebut boleh dikonsumsi langsung; (2) menjadi sumber penghasilan bagi usaha baru dan menambah pendapatan bagi usaha lanjutan; (3) meningkatkan kesejahteraan keluarga yang direpresentasikan pada perubahan positif dari
14 indikator kemiskinan standar BPS; (4) berubahnya pola pikir yang tidak pernah menyiapkan cadangan pangan, tidak pernah pernah berkelompok dan tidak pernah menabung, sekarang semua sudah pernah dilakukan. Progam bantuan pangan ini lebih optimal manfaatnya, jika peranan institusi pemerintah khususnya dalam pembinaan dan pemberdayaan ditingkatkan lagi. Peranan LSM diharapkan tidak hanya pada melakukan sosialisasi ulang dan praktek mengolah pangan bantuan saja, tetapi juga diharapkan lebih memberikan motivasi dan inovasi dalam variasi produk olahan pangan.

Meskipun sudah ada kebiasaan menabung, tetapi responden belum mau menabung di lembaga perbankan. Meskipun sudah terbiasa hidup berkelompok tetapi dalam prakteknya hanya untuk melakukan kegiatan menabung. Agar pola pikir bisa ditingkatkan maka disarankan dibuat kebijakan yang memudahkan responden menabung di bank, serta dibuat kegiatan-kegiatan lainnya di setiap pertemuan kelompok, sehingga bisa membuka wawasan baru di setiap responden.

\section{DAFTAR PUSTAKA}

Bappenas. 2002. Kebijakan dan Strategi Penanggulangan Kemiskinan Perkotaan : Sebuah Gagasan. Bappenas Jakarta

Checkoway, B. 1995. Six Strategies of Community Change. Community Development Journal Vol. 30, No 1. Oxford University Press Oxford

Gonsalves, J., T. Becker, A. Braun, D. Campilon, H. de Chaves, E. Fajber, M. Capiriri, J.R. Caminade and R. Vernoy (editor). 2005. Participatory Research and Development for Sustainable Agricultural and Natural Resource Management : A Resource Book (Glossary). International Potato Center Users Perspective with Agricultural Research and Development. Philippines

Mubyarto. 1984. Strategi Pembangunan Pedesaan. P3PK UGM Yogyakarta.

Sumarni S. Ketahanan dan Kerawanan Pangan. http://pelangigizi.wordpress.com/ketahan an dan kerawanan pangan/ 
Valeriana Darwis : Pelaksanaan Dan Manfaat Kegiatan Pemberdayaan Masyarakat...

Sajogyo.1982. Bunga Rampai Perekonomian Desa. Yayasan Agro Ekonomika. Jakarta

Syahyuti. 2007. Penerapan Pendekatan Pemberdayaan Dalam Kegiatan Pembangunan Pertanian : Perbandingan Kegiatan P4K, PIDRA, P4MI dan
Primatani. Forum Agro Ekonomi Volume 25 N0.2 Desember 2007. Pusat Analisis Sosial Ekonomi dan Kebijakan Pertanian

Tabloid Sinar Tani. 2012. Perlu Dibuat Peta Rawan Pangan di Perkotaan 